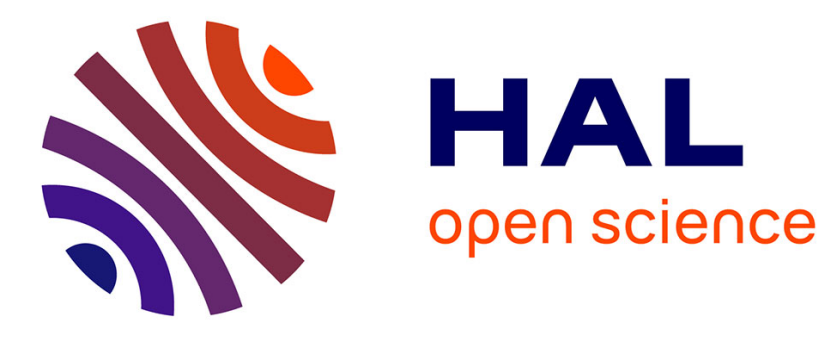

\title{
Interlaminar Mode-I Fracture Characterization Underwater of Reinforced Bituminous Specimens
}

Maïssa Gharbi, Armelle Chabot, Jean-Luc Geffard, Mai Lan Nguyen

\section{To cite this version:}

Maïssa Gharbi, Armelle Chabot, Jean-Luc Geffard, Mai Lan Nguyen. Interlaminar Mode-I Fracture Characterization Underwater of Reinforced Bituminous Specimens. RILEM International Symposium on Bituminous Materials (ISBM), Dec 2020, Lyon, France. pp.1119-1125 in RILEM Bookseries, vol. 27, 2022, 10.1007/978-3-030-46455-4_142 . hal-03012849

\section{HAL Id: hal-03012849 https://hal.science/hal-03012849}

Submitted on 18 Nov 2020

HAL is a multi-disciplinary open access archive for the deposit and dissemination of scientific research documents, whether they are published or not. The documents may come from teaching and research institutions in France or abroad, or from public or private research centers.
L'archive ouverte pluridisciplinaire HAL, est destinée au dépôt et à la diffusion de documents scientifiques de niveau recherche, publiés ou non, émanant des établissements d'enseignement et de recherche français ou étrangers, des laboratoires publics ou privés. 


\title{
Interlaminar Mode-I Fracture Characterization Underwater of Reinforced Bituminous Specimens
}

\author{
Maïssa Gharbi ${ }^{1[0000-0002-5720-9943]} *$, Armelle Chabot ${ }^{2[0000-0002-9430-8457]}$, Jean-Luc Geffard ${ }^{2}$, \\ Mai Lan Nguyen 2[0000-0001-8966-5209] \\ ${ }^{1}$ French Civil Aviation Technical Center (STAC), Bonneuil-sur-Marne, France \\ ${ }^{2}$ MAST-LAMES, Univ Gustave Eiffel, IFSTTAR, F-44344 Bouguenais, France \\ * maissa.gharbi@ regis-dgac.net
}

\begin{abstract}
In order to investigate the interlaminar mode I fracture behavior of pavements, Wedge Splitting Tests (WST) have been developed for specimens extracted directly from field sections. As part of the French SolDuGri project focusing on bituminous pavement reinforced by glass fiber grids, WST are applied under static loads and different climatic conditions. This paper highlights the impact of water on such an interlaminar bond characterization. Results derived from samples of five to ten specimens (unreinforced or reinforced with two types of grids) tested under each type of conditions are reported here. The Digital Image Correlation (DIC) technique has been used herein. Depending on the glass fiber grid used, the observation of fractured interfaces and splitting force-crack mouth opening displacement (CMOD) curves does reveal differences. The presence of water in the bituminous emulsion influences on the dispersion of results depending on some type of interfaces. These interlaminar mode-I fracture characterizations should yield greater insight into results recently obtained from accelerated pavement tests conducted on the IFSTTAR fatigue carousel.
\end{abstract}

Keywords: Fiber grids, Interface, Moisture, Wedge Splitting Test, Digital Image Correlation.

\section{Introduction}

In an effort to delay the reflective cracking propagation phenomenon or to reinforce top bituminous layers, one of the main ideas proposed for roads by the fiber manufacturing industry is to insert grids into bituminous pavement structures [1-3]. The durability of such composite structures depends in part on ensuring a strong bond between grids and bituminous materials. This condition is essential, especially when using grids inside top pavement layers. Along with rolling loads and temperature variations, the presence of water near the interface must be considered in studying debonding mechanisms [4]. To better understand the interlaminar mode I fracture

This paper presented at RILEM ISBM Lyon 2020 is accepted for publication in the RILEM Bookseries Vol. 27, that it is copyrighted by RILEM @2021. Readers must contact RILEM for permission to reprint or use the material in any form. The original publication is available at web site of the Springer International Publishing's: https://www.springer.com/gp/book/9783030464547 
behavior of pavements, Wedge Splitting Tests (WST) have been developed, whether underwater or not, for specimens extracted directly from road sections [5-6]. These tests have displayed rather interesting results, in comparison with results obtained on actual pavement test sections. As part of the French SolDuGri project (ANR-14CE22-0019), which examines bituminous pavement reinforced by glass fiber grids [7], WST are applied under static loads and different climatic conditions. Subsequent to works aimed at characterizing the interfacial bond of multilayer composite specimens [8], a water immersion WST was introduced. This paper briefly presents the WST equipment and testing campaigns before giving the main results obtained and then drawing a conclusion.

\section{Underwater WST and Specimen Characterization}

Extracted from in situ bituminous sections and in accordance with a RILEM recommendation [4], a large number of specimens differentiated by both type and testing conditions were prepared and assessed [5]. Specimen dimensions were chosen so that the interface dimensions contained a minimum of $3 \times 3$ grid meshes [6]. This project's two selected glass fiber grids, denoted G3 and G4 for P6 and P7 specimen types respectively, have a mesh size of $40 \times 40 \mathrm{~mm}^{2}$. Their tensile strength equals $100 \mathrm{kN} / \mathrm{m}$, with the two grids differing from each other in the type of coating resins employed (stiffer for G3) [7]. They were glued with a $500 \mathrm{~g} / \mathrm{m}^{2}$ bitumen emulsion applied on the bituminous material layers $\left(\mathrm{E}=11,300 \mathrm{MPa}\right.$ at $15^{\circ} \mathrm{C}$ and $10 \mathrm{~Hz} ; \mathrm{v}=$ $0.35)$. Due to the field compaction conditions, the bituminous material displayed average void contents of $4 \%$ and $6 \%$ below and above of the grid respectively; it was composed, in accordance with French bituminous mix standard NF EN 13108-1, using an aggregate size of $0 / 10$ and $5.6 \%$ bitumen of $35 / 50$ penetration grade.
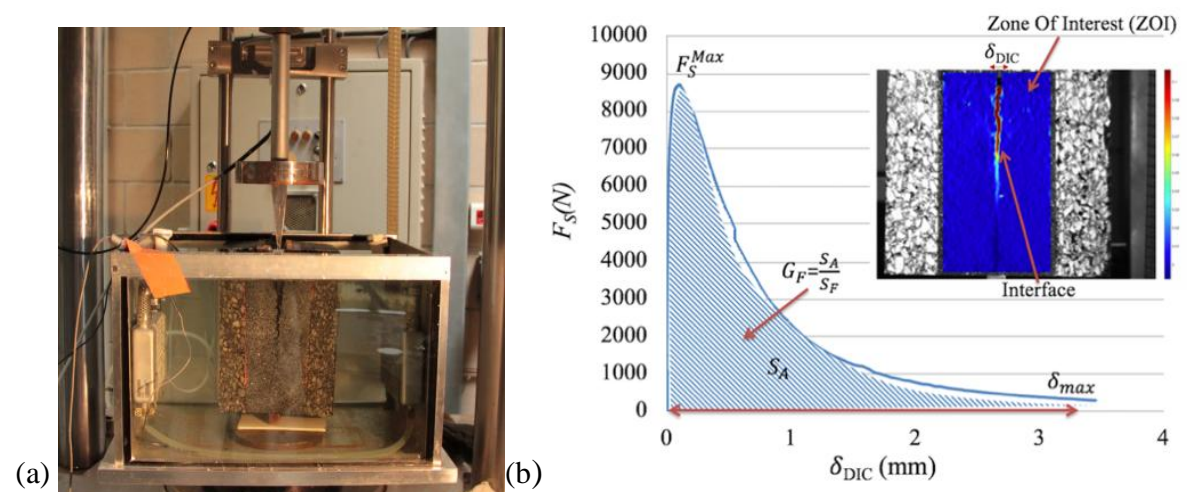

Fig. 1. WST: a) Specimen tested under water, b) the 3 indicators of the $F_{S}-\delta_{\text {DIC }}$ curve

Similarly to Chabot et al. [8], an aquarium designed for testing specimens under water was built (Fig. 1a). The specimens were first vacuum-saturated with water at a depressurization of up to $86 \mathrm{kPa}$ (15 min in an air box, then $2 \mathrm{~h}$ in water). Next, they were stored in a water bath at around $20^{\circ} \mathrm{C}$ before being tested under the static 
condition of a controlled $2 \mathrm{~mm} / \mathrm{min}$ displacement. Considering " $\alpha$ " (equal to $7^{\circ}$ here) as one-half the wedge angle, the splitting load can be written: $F_{S}=2 F_{H} ; F_{H}=$ $F_{M} / 2 \operatorname{tg}(\alpha)$. During testing, both the Crack Mouth Opening Displacement (CMOD) and crack propagation length were measured by means of the Digital Image Correlation (DIC) technique (Fig. 1b).

From the WST load-displacement curve (splitting load $\left(\mathrm{F}_{\mathrm{S}}\right)-\mathrm{CMOD}\left(\delta_{\mathrm{DIC}}\right)$ ), Fig. $1 b)$, the debonding propagation resistance of the interface is classically obtained by determining the specific fracture energy $G_{F}$ given in Eq. 1, i.e.:

$$
\mathrm{G}_{\mathrm{F}}=\frac{\mathrm{s}_{\mathrm{A}}}{\mathrm{S}_{\mathrm{F}}}
$$

In Eq. $1, S_{F}$ is the fracture area of the specimen and $S_{A}$ the splitting energy calculated from the area under the $F_{S}-\delta_{\text {DIC }}$ curve (Fig. 2b). From this curve, results depending on the three values of $F_{S}, G_{F}$ and $\delta_{\text {DIC }}$ can be compared as follows.

From more than 100 prepared specimens, dedicated to studying the effects of water on the various types of interfaces, fracture debonding mode I tests were conducted first at ambient temperature in air and then under water at around $20^{\circ} \mathrm{C}$. Moreover, in order to obtain information on the temperature effect, the reinforced $\mathrm{P} 7$ specimens (i.e. with the G4 grid inserted) were tested under a colder water of around $7^{\circ} \mathrm{C}$. All the testing conditions have been repeated at least ten times. However, some of the first tests performed (not reported here) have been interrupted due to a bad geometry of the samples resulting from the sawing process. Table 1 summarizes the average moisture characteristics of each specimen type and underwater testing condition.

Table 1. Moisture characteristics of specimens tested under water.

\begin{tabular}{lcccccc}
\hline $\begin{array}{c}\text { Specimen } \\
\text { name }\end{array}$ & $\begin{array}{c}\text { Test } \mathrm{T} \\
\left({ }^{\circ} \mathrm{C}\right)\end{array}$ & $\begin{array}{c}\text { Dry } \\
\text { mass }(\mathrm{g})\end{array}$ & $\begin{array}{c}\text { Wet } \\
\text { mass }(\mathrm{g})\end{array}$ & $\begin{array}{c}\text { Absorbed water } \\
\text { volume }\left(\mathrm{cm}^{3}\right)\end{array}$ & $\mathrm{S}_{\mathrm{r}}$ & $\begin{array}{c}\text { Immersion } \\
\text { time (h) }\end{array}$ \\
\hline P8 & $\sim 20^{\circ} \mathrm{C}$ & $\sim 15320$ & $\sim 15540$ & $\sim 157(103$ to 238$)$ & $\sim 48(31$ to 71$)$ & $\sim 45(26$ to 74$)$ \\
P6 (G3) & $\sim 20^{\circ} \mathrm{C}$ & $\sim 15130$ & $\sim 16132$ & $\sim 180(118$ to 250$)$ & $\sim 52(37$ to 66$)$ & $\sim 26(21$ to 28$)$ \\
P7 (G4) & $\sim 20^{\circ} \mathrm{C}$ & $\sim 14550$ & $\sim 14680$ & $\sim 130(103$ to 189$)$ & $\sim 43(34$ to 61) & $\sim 41$ (7 to 96) \\
P7 (G4) & $\sim 7^{\circ} \mathrm{C}$ & $\sim 14551$ & $\sim 14900$ & $\sim 133(83$ to 265) & $\sim 42(28$ to 83$)$ & $\sim 36(18$ to 98$)$ \\
\hline
\end{tabular}

Each specimen was weighed both before and after being saturated with water. Its absorbed water volume could then be evaluated as a function of void content. According to European Standard NF EN 12697-12, the degree of saturation $\left(\mathrm{S}_{\mathrm{r}}\right)$ for each specimen was calculated and reported in Table 1.

\section{$3 \quad$ Results and Discussion}

Figure 2 summarizes the WST results obtained both in air and under water at around $20^{\circ} \mathrm{C}$. Under these two testing conditions, it is shown that regardless of the grid used to reinforce the bituminous material, i.e. G3 or G4 grid for a P6 or P7 specimen, respectively: 
- The maximum bonding value of $F_{S}^{M a x}$ is smaller for P6 and P7 specimens than for unreinforced P8 specimens, whose value reaches $100 \%$ in underwater tests (Fig. 2a);

- The fracture energy $\mathrm{G}_{\mathrm{F}}$ obtained, for the same value of $\delta_{\mathrm{DIC}}=4 \mathrm{~mm}$, is reduced for P6 and P7 specimens compared to unreinforced P8 specimens, whose $\mathrm{G}_{\mathrm{F}}$ value reaches $100 \%$ in air (Fig. 2b).

These two results lead to concluding that compared to unreinforced P8 specimens, the interfacial bond characteristics of reinforced P6 specimens (with a G3 grid) and reinforced P7 specimens (G4 grid) are reduced by roughly $1 / 3$ relative to the crack initiation process and by $2 / 3$ relative to propagation resistance.
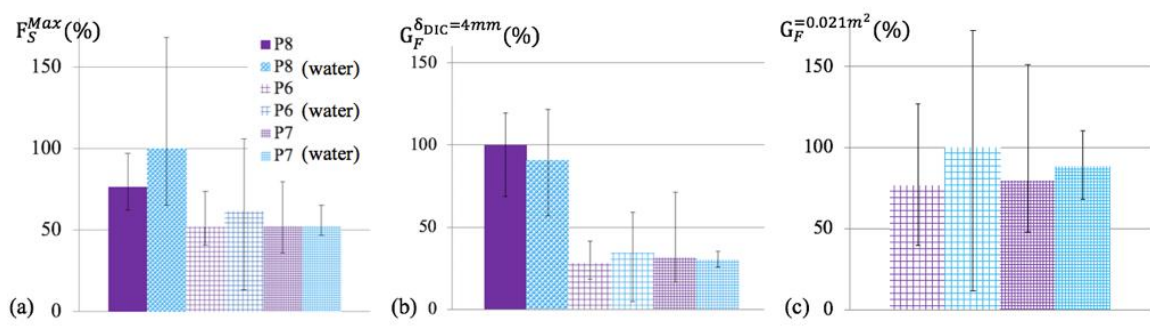

Fig. 2. Comparison of results (normalized values): a) $F_{S}^{M a x}$, b) $\mathrm{G}_{F}^{\delta_{\text {DIC }}=4 m m}$, c) $\mathrm{G}_{F}^{=0.021 m^{2}}$

The fracture energy $G_{F}$ values reported in Figures $2 b$ and $2 c$, for the same fracture area (i.e. $S_{\mathrm{F}}=0.021 \mathrm{~m}^{2}$, corresponding to an average crack length of around $0.140 \mathrm{~m}$, as measured by DIC), illustrate that the dispersion in results under water is greater for both P8 specimens and reinforced P6 specimens in comparison with reinforced P7 specimens. Delamination at the interface may have occurred in the tack coat for P8 and P6 specimens, while it clearly occurred in the P7 grid. Figure 3 shows that the G4 grid has broken in all parts of P7 specimen interfaces [5]. This outcome is also observed at $7^{\circ} \mathrm{C}$ (Fig. 3b).

(a)

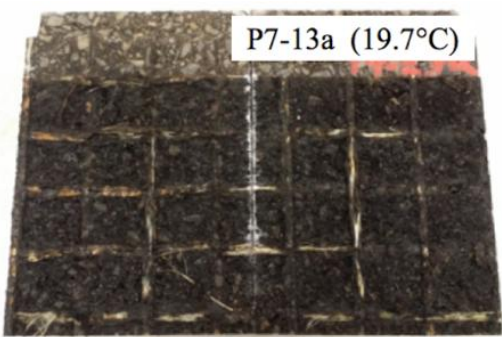

(b)

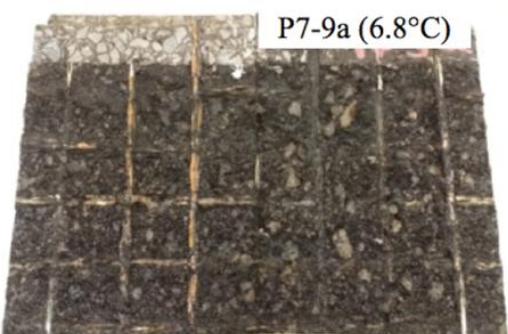

Fig. 3. Fracture surface view of a reinforced $\mathrm{P} 7$ specimen tested under water:

$$
\text { a) } \sim 20^{\circ} \mathrm{C}, \text { b) } \sim 7^{\circ} \mathrm{C}
$$

From the literature, it has been shown that water and immersion times may exert a negative influence on the interlayer bond. This influence has been demonstrated by means of shear fracture testing at hot temperatures (i.e. $40^{\circ} \mathrm{C}$ to $60^{\circ} \mathrm{C}$ ) [9] as well as 
mixed-mode testing between cement and bituminous materials around $20^{\circ} \mathrm{C}$ [8]. No clear effect of water has been found here, except on the dispersion of results. However, the dispersion of WST results, for the interfaces between such bituminous materials tested under fracture mode $\mathrm{I}$ at $20^{\circ} \mathrm{C}$ and $7^{\circ} \mathrm{C}$, is not due to differences in the limited specimen storage time in water (Table 1). In fact, during the test, the water itself was responsible for altering tack coat strength among all specimens tested under water, except for P7. The G4 grid bonded to the tack coat seems to have altered bitumen resistance by further destroying the adhesion between the granular layer and the bitumen. Moreover, fracture surface observations at low temperature around $7{ }^{\circ} \mathrm{C}$ (Fig. 3b) highlight this phenomenon to a greater extent than observations at $20^{\circ} \mathrm{C}$ (Fig. 3a). Indeed, the mode I fracture energy spent for debonding reinforced $\mathrm{P} 7$ specimen interfaces at $7^{\circ} \mathrm{C}$ exceeds that spent at $20^{\circ} \mathrm{C}$ (Fig. 4).

(a)
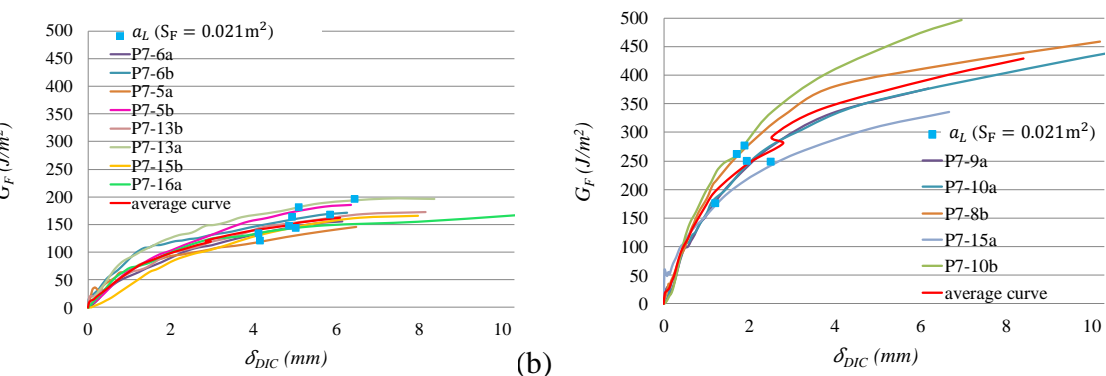

Fig. 4. $\mathrm{G}_{\mathrm{F}}$ results for reinforced $\mathrm{P} 7$ specimens tested under water: (a) $\sim 20^{\circ} \mathrm{C}$, (b) $\sim 7^{\circ} \mathrm{C}$

\section{Conclusion}

In conjunction with four-point bending fatigue tests and accelerated loading tests (APT) conducted on several pavement structures throughout the course of the French SolDuGri project (ANR-14-CE22-0019) [10], the WST has been developed specifically for specimens extracted from road sections [5-6]. This approach has led to experimentally characterizing the Interlaminar Mode-I Fracture of the interlayer bond of pavement reinforced with fiberglass grids. To investigate the effect of moisture on the interlayer bond, a water immersion WST has also been proposed. In this paper, the WST campaigns were carried out in air and under water. The final fracture surface observations and the splitting force-CMOD curve results for 3 types of specimens have been presented. Two types of grids, denoted G3 and G4, were used; they only differ from each other in the coating resins applied. The resin used for the G3 grid is stiffer than the one used for the G4 grid [7]. Compared to the WST results of unreinforced specimens, the bond between bituminous layers when adding these two grids is reduced for both by roughly $1 / 3$ relative to crack initiation and by $2 / 3$ relative to propagation resistance. At $20^{\circ} \mathrm{C}$, the presence of water in the materials exerts an influence on the dispersion of all results, except for specimens reinforced with the G4 grid. For the G4 grid, WST results under water at two temperatures $\left(7^{\circ} \mathrm{C}\right.$ and $\left.20^{\circ} \mathrm{C}\right)$ 
illustrate the thermal effect on bonding behavior; also, it was shown that the G4 grid does indeed adhere to the bituminous material. The fracture mechanisms are localized inside the G4 grid itself and on the bond between aggregates and tack coat bitumen emulsion. This laboratory study yields greater understanding of some of the poor interface bond results obtained recently in the field during the APT campaign.

Acknowledgements The work presented in this paper was sponsored by the French National Research Agency (ANR-SolDuGri project ANR-14-CE22-0019).

\section{References}

1. Nguyen, M.-L., Blanc, J., Kerzreho, J.-P., Hornych, P.: Review of glass fibre grid use for pavement reinforcement and APT experiments at IFSTTAR. Road Materials and Pavement Design 14 (sup1), 287-308 (2013).

2. Chabot, A., Buttlar, W.G., Dave, E.V., Petit, C., Tebaldi, G. (eds): 8th RILEM Int. Conf. on Mechanisms of Cracking and Debonding in Pavements. RILEM Bookseries, vol. 13, $1^{\text {st }}$ Ed., Springer Netherlands (2016). doi: 10.1007/978-94-024-0867-6

3. Canestrari, F., D’Andrea, A., Ferrotti, G., Graziani, A., Partl, M.N., Petit, C., Raab, C., Sangiorgi, C.: Advanced Interface Testing of Grids in Asphalt Pavements. In: Partl, M., Porot, L., Di Benedetto, H., Canestrari, F., Marsac, P., Tebaldi, G. (eds), RILEM State-ofthe-Art Reports Vol. 24, pp. 127-202. Springer, Cham (2018).

4. Petit, C., Chabot, A., Destrée, A., Raab, C.: Recommendation of RILEM TC 241-MCD on Interface Debonding Testing in Pavements. Materials and Structures 51 (4), article 96 (2018)

5. Gharbi, M. : Caractérisation du collage des interfaces de chaussées par essais de rupture en mode I. ECN PhD thesis, ED SPI (http://www.theses.fr/2018ECDN0037/document) (2018).

6. Gharbi, M., Nguyen, M.L., Trichet, S., Chabot, A.: Characterization of the bond between asphalt layers and glass fiber grid with help of a Wedge Splitting Test. In Loizos, A., AlQadi, I., Scarpas T. (eds) BCRRA 2017, pp. 1517-1524. CRC Press, London, UK (2017). doi: 10.1201/9781315100333-201

7. Doligez D., Godard E., Gharbi M., Chazallon C., Hornych P., Chabot A., Nguyen M.L.: For Sustainable Reinforcements of Infrastructures with Glass Fiber Grids. XXVIth World Road Congress, 6-10 October, Abu Dhabi (2019).

8. Chabot, A., Hammoum, F., Hun, M.: A 4pt bending bond test approach to evaluate water effect in a composite beam. European Journal of Environmental and Civil Engineering 21 (sup1), 54-69 (2017)

9. Raab, C., Partl, M.N., Abd El Halim, AO.: Experimental Investigations of Moisture Damage in Asphalt. Int. J. Pavement Res. Technol. 5(3),133-141, (2012).

10. Nguyen ML, Chazallon C., Sahli M., Koval G., Hornych P., Doligez D., Chabot A., Le Gal Y., Brissaud L., Godard E. Design of reinforced pavements with glass fiber grids: from laboratory evaluation of the fatigue life and its FEM/DEM modelling to accelerated full-scale test. In: Chabot A., Hornych P., Harvey J., Loria-Salazar L. (eds) Accelerated Pavement Testing to Transport Infrastructure Innovation, LNCE, vol. 96: 329-338, Springer, Cham, (2020). https://doi.org/10.1007/978-3-030-55236-7_34. 